\title{
Osoba po przeszczepieniu narządu doświadczająca jakości życia - jako przedmiot zainteresowań pedagogów
}

\author{
KEY WORDS \\ experiencing of life \\ quality, transplant, \\ new educational \\ challenges, organ \\ recipient, organ donor
}

\begin{abstract}
Cymerman Iwona, Osoba po przeszczepieniu narzadu doświadczająca jakości życia-jako przedmiot zainteresowań pedagogów [Individual After Transplantation Experiencing Quality of Live - Subject of Pedagogues Interest]. Kultura - Społeczeństwo - Edukacja nr 2, 2012, Poznań 2012, pp. 97-118, Adam Mickiewicz University Press. ISBN 978-83-232-2528-7
\end{abstract}

Pedagogy has been recently becoming more and more interdisciplinary, deriving from achievements of others humanities. In modern, complicated world it could be rather impossible not to benefit from such advantage, as it would push aside pedagogy and others fields of knowledge to margin, falling it back rather than giving them prospect of growth. That is why issue of organ transplantation, for instance, although it seems stricte medical problem, now expands area of pedagogy interests. It concerns all the situations having significance in experiencing quality of life by the pedagogical entities, so pupils in each age.

This text is based on description of experiencing life's quality of one person, living thanks to liver transplantation. It had been 10 years after surgery when Zygmunt was giving me interview. I hold a second conversation with him, as earlier he had been exchanging with me his experiencing quality of life. For the first time I met my interlocutor in September 2001, at that moment, he had been only three months after transplantation. Experiencing day-to day-reality of family, work, seeing with medical personnel during necessary consultation, this time were important for me. As a scientist I was interested also in changes that had been emerging and still appears in the context of quality life experiencing, from that moment when we had a first conversation. Feeling of life sense, recognized values were significant for me. Quality analysis, having attributes of phenomenological description of experiencing Zygmunt's quality life is often supplementing by medical, legal, ethical and religious data. I have done this, so that to in abbreviated way expose issues, shaping new research fields and new areas of educators' activities in the context of transplantation. Zygmunt's narrative is individual and for that reason it is not justified to make generalized conclusions. In the last part of text I am taking up efforts to justify significance of discussed issue (experiencing quality of life after transplantation). 
Pedagogika staje się coraz bardziej interdyscyplinarna, czerpie z dorobku innych nauk. We współczesnym, skomplikowanym świecie byłoby już raczej niemożliwe niekorzystanie z tego dobrodziejstwa, bowiem spychałoby to pedagogikę, jak i każdą inną dziedzinę wiedzy, na margines, uwsteczniający ją i zamykający perspektywy rozwoju. Na przykład, problematyka transplantacji narządów, choć wydaje się stricte medycznym zagadnieniem, rozszerza obszar zainteresowań pedagogiki, zajmują ją bowiem wszelkie sytuacje dotyczące podmiotów pedagogicznych, czyli (szeroko rozumianych i znajdujących się w każdym wieku) wychowanków, mające znaczenie w doświadczanej przez nich jakości życia.

Niniejszy tekst jest oparty na opisie przeżyć doświadczania jakości życia jednej osoby żyjącej dzięki transplantacji wątroby. Zygmunt w chwili udzielania mi wywiadu był dziesięć lat po tym zabiegu'. Rozmowę z nim przeprowadzałam po raz drugi, bowiem już dzielił się on ze mną swoim doświadczaniem jakości życia². Pierwszy raz z moim rozmówcą spotkałam się we wrześniu 2001 r., w chwili, gdy był zaledwie trzy miesiące po przeszczepieniu wątroby. Powtórny wywiad przeprowadziłam z nim po niemal całej dekadzie lat jego życia z implantowanym organem, czyli w lipcu 2011 r. Ważna zatem była dla mnie doświadczana codzienność w rodzinie, pracy, jak również $\mathrm{w}$ kontaktach z personelem medycznym podczas koniecznych wizyt kontrolnych. Mnie, jako badacza, interesowały także zmiany, jakie nastąpiły i zachodzą w kontekście doświadczania jakości życia od czasu pierwszej rozmowy. W obrębie niniejszych zagadnień znaczenie dla mnie miało poczucie sensu życia oraz uznawane wartości. Analiza jakościowa, mająca znamiona fenomenologicznego opisu doświadczania jakości życia Zygmunta, jest niejednokrotnie przeplatana danymi z zakresu aspektów medycznych, prawnych, etycznych czy religijnych. Dokonuję takiego zabiegu, aby w skrótowy sposób naświetlać kwestie wyznaczające nowe tereny badawcze oraz tereny działań dla pedagogów w kontekście transplantacji organów. Narracja Zygmunta jest jednostkowa i, co oczywiste, $\mathrm{z}$ tej racji nie jest zasadne rozszerzenie opowiadanych przeżyć $\mathrm{w}$ celu uogólniania wniosków.

W ostatniej części tekstu podejmuję starania, by uzasadnić ważkość omawianej problematyki (doświadczania jakości życia po przeszczepie) na gruncie pedagogiki. Aspekty, które nie zostały przedstawione we wcześniejszej części artykułu, zawieram w tej właśnie części końcowej, podsumowującej.

${ }^{1}$ Aby zapewnić anonimowość mojemu rozmówcy, imię oraz niektóre dane zostały zmienione. Jednakże starałam się, aby zabieg ten nie wpłynął na istotę opisu doświadczania jakości życia badanej przeze mnie osoby.

${ }^{2}$ Przeżycia Zygmunta szczegółowo opisane (oraz innych osób po transplantacji wątroby oraz żyjących z przeszczepioną nerką) z tamtego okresu znalazły się w książce: I. Cymerman, Doświadczanie jakości życia po przeszczepie. Perspektywa fenomenologiczno-hermeneutyczna, Wyd. UWM, Olsztyn 2007. 


\section{Ustalenia terminologiczne}

Transplantacja narządów jest jednym z ważniejszych osiągnięć współczesnej medycyny. Jak zauważa J. Szczerbań w 1998 r.: „jest najskuteczniejszą interwencją ratującą życie chorym z nieuleczalną i postępującą niewydolnością nerek, serca, wątroby" (Szczerbań, 1998: 394). Obecnie, jeśli chodzi o narządy, dokonuje się już przeszczepień trzustki jednocześnie z nerką, serca i płuca oraz obu płuc. Transplantologia, jak stwierdza W. Rowiński: „W tej chwili już nikt nie podaje, jaki odsetek chorych żyje ile lat po przeszczepie narządu, tylko jaka jest jakość ich życia. W specjalny sposób przelicza się liczbę lat przeżytych przez pacjentów w dobrym stanie zdrowia" (Rowiński, 2003).

Określenie jakości życia na użytek niniejszych rozważań z jednej strony sytuuje się $\mathrm{w}$ intuicyjnym pojmowaniu tego stanu rzeczy przez osobę badaną, $\mathrm{z}$ drugiej zaś rozpościera się w interdyscyplinarnym kontekście polisemicznego ujęcia. Wynika bowiem z doświadczeń badaczy zajmujących się jakością życia, „że pomiaru jakości powinno dokonywać się według kryteriów subiektywnych, gdyż każdy człowiek sam ustala własną miarę. Ocena poziomu jakości życia jest porównaniem oczekiwań i stanu rzeczywistego. O zadowoleniu mówimy wówczas, gdy odczucia są zgodne $\mathrm{z}$ oczekiwaniami lub nawet je przewyższają, w przeciwnym razie dochodzi do negatywnego bilansu" (Sokolnicka, 2003: 2). Potwierdza to W. Chańska, analizując mierzenie jakości życia w medycynie według różnych autorów. Powołując się na rozważania L. Nordenfelta, zauważa, iż: „Do tego, aby być szczęśliwym, wystarczy, (...) iż dana osoba wierzy, że konkretny przedmiot bądź zdarzenie stanowi spełnienie jej pragnienia" (Chańska, 2009: 290). Na ogół każdy sam definiuje jakość swojego życia i według własnego spojrzenia subiektywnie ocenia osobistą sytuację życiową. Z reguły człowiek obserwuje życie przez pryzmat bagażu swoich osobistych doświadczeń, według własnej hierarchii wartości i aspiracji życiowych. Na dodatek wartości ewoluują, a doświadczenia historii życia powiększają się, choć należy pamiętać, iż człowiek „funkcjonuje w świecie jako jednostka doświadczająca, nie rejestrując wszystkiego w pamięci. Tylko bowiem niektóre ze zjawisk doświadczanych, w zależności od historii życia indywiduum, przesądzają o interpretacji, a także o ich następstwach, pozostawiając bardziej lub mniej trwałe ślady w pamięci” (Ostrowska, 1998: 65). Podobnie jak podczas moich badań z lat 2000-2003, tak i tu starałam się określić poziomy doświadczania jakości życia (por. Cymerman, 2007: 34). Wyłoniłam trzy takie sposoby przeżywania: niski, ambiwalentny oraz wyskoki/optymalny. Pierwszy poziom - niski - wskazuje na poważny rozdźwięk pomiędzy ustalonym przez siebie stanem idealnym (dotyczącym jakości życia) a przeżywaną rzeczywistością. Sytuowanie doświadczanej przez siebie jakości życia na poziomie ambiwalentnym dotyczy zwłaszcza takich 
momentów egzystencji, kiedy występuje sytuacja "niepewnego losu” człowieka, gdy ów los ewoluuje w znacznym tempie, np. w momencie zmiennych stanów zdrowia osoby poważnie chorej. Zaś poziom wysokiego/optymalnego doświadczania jakości życia jest udziałem człowieka, który jest zadowolony ze swego bytu, realizuje się, dążąc do celu przez siebie wyznaczonego. Ma również ukonstytuowany sens własnej egzystencji. Warto zauważyć, iż w tych poziomach doświadczania jakości własnego życia nie umiejscawiam ekstremalnych poziomów, czyli braku oraz wynaturzonego ponad miarę poziomu. Wydaje się bowiem, że można doświadczać nawet bardzo niskiej jakości własnego istnienia, ale nie całkowitego jej braku. „Jakąss” jakość zawsze człowiek odczuwa. W drugim zaś przypadku trudno sobie również wyobrazić kogoś, kto uzna, że przeżywa nazbyt wysoką jakość życia. Bowiem choć potencjalnie da się stwierdzić: żyje ponad stan, jednakowoż jest to zawężenie całości doświadczania do zaledwie aspektu materialnego. Tymczasem termin 'doświadczanie' rozumiem jako immanentne oraz permanentne obcowanie ze sobą samym, ludźmi w wydarzeniach (bycie w ich centrum bądź blisko nich) życia. Owo obcowanie znamionuje stale dokonującą się przemianę doświadczania zarówno w sferze postrzegania oraz odbierania świata wewnętrznego, a także zewnętrznego, jak i w kwestii biologicznej, na przykład toczący się proces starzenia się organizmu, czy jak w przypadku przeszczepu organu częściowa odbudowa/ odnowa zdegradowanego chorobą ciała ${ }^{3}$.

\section{Zygmunt}

W rozważaniach zagadnienia jakości życia doświadczanej przez osobę żyjącą z przeszczepionym narządem (przez podmiot pedagogiczny) nie wolno pominąć okresu, który poprzedzał obecny czas, mianowicie: egzystencja przed transplantacją. Mój rozmówca - Zygmunt (56 lat) od wczesnego dzieciństwa często chorował i wielokrotnie był leczony szpitalnie. Od 1993 r. zaczął odczuwać dolegliwości spowodowane nieprawidłowym funkcjonowaniem wątroby, które objawiały się uporczywym świądem skórył. Przyczyną okazał się niszczący ten organ wirus powodujący przewlekłe wirusowe zapalenie wątroby typu C. Stan zdrowia Zygmunta pogarszał się stopniowo, doprowadzając do krwotoków z przełyku, spowodowanych żylakami przełyku charakterystycznymi w postępującej marskości wątroby.

${ }^{3}$ Niniejszy akapit jest napisany na podstawie opisu ryciny 2., którą opracowałam w książce: Doświadczanie jakości życia po przeszczepie... (Cymerman, 2007: 34); na podstawie rozważań własnych o doświadczanej jakości życia - tamże: 46-47; a także na kanwie wyjaśnień dotyczących ujmowania przeze mnie pojęcia doświadczanie - tamże: 31 .

${ }^{4}$ Świąd skóry występuje u $20 \%$ pacjentów zarażonych wirusowym zapaleniem wątroby. Kwasy żółciowe „powodują podprogowe podrażnienie włókien czuciowych, przejawiające się klinicznie właśnie świądem” (Knapik, 1998: 112). 
Do tego dołączyły się encefalopatie ${ }^{5} \mathrm{w}$ postaci trudności w skupieniu się i kłopoty z pamięcią. To wszystko bardzo utrudniało życie codzienne zarówno mojemu rozmówcy, jak i jego bliskim. Niewątpliwie taki stan rzeczy bardzo obniżał doświadczaną wówczas jakość życia przez mojego rozmówcę. Chorzy cierpiący z powodu coraz mniej prawidłowej pracy wątroby prócz symptomów, które doświadczał mój rozmówca, mogą doświadczać również, między innymi: zażółcenia, wodobrzusza, spadku sił fizycznych, a przede wszystkim wspomnianych wyżej encefalopatii. Te ostatnie objawy mogą jednak prowadzić do dużo większej degradacji organizmu niż te, które były udziałem mojego rozmówcy, poprzez na przykład drżenie dłoni, kłopoty z pamięcią, nieadekwatne reagowanie na bodźce, zwykle agresywne, aż do wątrobowej śpiączki, która, niestety, nie zawsze jest procesem odwracalnym (jeśli w porę nie nastąpi przeszczep, zazwyczaj pacjent umiera). Wprawdzie możliwe jest już obecnie oczyszczanie organizmu chorej osoby za pomocą sztucznej wątroby, jednakże z uwagi na znikomą liczbę tego typu aparatur, których jest zaledwie kilka w naszym kraju, oraz bardzo wysokie koszty dializy wątrobowej z użyciem ludzkich albumin, nie można liczyć na taką egzystencję (poza incydentalnymi wypadkami). Jedynym ratunkiem jest transplantacja wątroby. Inaczej jest w przypadku schorzeń nerek. Postępująca niewydolność tego parzystego organu sprawia, iż, między innymi, traci się siły fizyczne, apetyt, a w ekstremalnych sytuacjach nawet wzrok (gdy zbyt długo nie zostanie oczyszczony organizm; na szczęście jest to odwracalne poprzez oczyszczenie organizmu za pomocą dializy). Gdy całkowicie zanikną funkcje pracy nerek, do dalszej egzystencji człowieka niezbędne jest stosowanie dializy nerkowej przez kilka godzin dwa, trzy razy w tygodniu ${ }^{6}$. Jednakże wymuszone zostaje drastyczne ograniczenie spożywania białka oraz przyjmowania płynów przez chorego. Poza tym, wskutek stosowania sztucznego pozanerkowego oczyszczania organizmu, niezbędne jest przystosowanie planu życia codziennego do kalendarza dializ. Stosowanie sztucznej nerki niesie ze sobą jednak wiele skutków ubocznych, jak chociażby u kobiet trudności/niemożność zajścia w ciążę i donoszenie 7 . Dlatego swoistą pomocą, ratunkiem dla osób zmuszonych do takiej egzystencji jest przeszczep nerki.

Tymczasem mój rozmówca został wreszcie zakwalifikowany do przeszczepu wątroby, przeszedłszy wszystkie wymagane badania. Przed dokonaniem zabiegu

5 Encefalopatie, czyli zespół neuropsychiatryczny, spowodowany uszkodzeniem wątroby. Wspólną cechą są zaburzenia psychiczne, neurologiczne i uszkodzenia miąższu wątroby (por. Kokot, 1998: 160).

${ }^{6}$ Istnieje możliwość zastąpienia pracy nerek sztucznym jej zastępnikiem i dokonywaniem dializy pozaustrojowej (hemodializa) co dwa, trzy dni, bądź też dializy otrzewnowej, który jest zabiegiem oczyszczania pozanerkowego poprzez wykorzystanie właściwości półprzepuszczalnych błony jamy otrzewnej (zob. Wielki słownik medyczny, 1996: 272).

7 Takie właśnie niezmiernie bolesne doświadczenie miała jedna z osób przeze mnie badanych żyjąca z przeszczepioną nerką (Cymerman, 2007: 34). 
transplantacji bowiem pacjenci przechodzą serię badań, które nazywane są kwalifikacyjnymi do tego zabiegu. Wykonywane są podczas hospitalizacji pacjenta, trwają zazwyczaj kilka dni lub dłużej (zależnie od organizacji danej placówki oraz stanu zdrowia pacjenta).

Zaledwie po trzech miesiącach od otrzymania oficjalnego powiadomienia o zakwalifikowaniu się do przeszczepu Zygmunt został wezwany do kliniki w Warszawie na zabieg. Podobne powiadomienie otrzymuje zwykle kilku pacjentów naraz. Postępuje się tak, by zminimalizować ryzyko wystąpienia sytuacji, w której konieczne by było odstąpienie od zabiegu z powodu na przykład opryszczki wargowej potencjalnego biorcy. Oznaczałoby to wówczas konieczność kolejnego wzywania innego pacjenta, który spełniałby odpowiednie kryteria medyczne dostosowane do danego narządu przygotowywanego do implantacji. Odwlekałoby to wykonanie zabiegu o kolejne godziny i zmniejszałoby szanse na dobre rokowania stanu pacjenta po przeszczepie. Okres oczekiwania na wezwanie do kliniki w celu przeszczepienia narządu bywa dłuższy niż jak w przypadku mojego rozmówcy. O tym, komu zostanie implantowany dany organ, decydują względy medyczne (wystarczająca zgodność antygenowa dawcy i biorcy, stopień niewydolności narządu, który ma być zastąpiony, stan chorego czekającego na przeszczep itp.). Dlatego też nieraz się zdarza oczekującym pacjentom być wzywanym nawet kilkakrotnie, zanim zostanie wszczepiony im potrzebny narząd. Może się wszak okazać, jak zostało przed chwilą wspomniane, że dany pacjent akurat przechodzi infekcję wirusową, która $\mathrm{w}$ danej chwili uniemożliwia wykonanie zabiegu, po transplantacji bowiem stosowane leczenie immunosupresyjne obniżające siły obronne organizmu biorcy stwarzałoby zagrożenie dla jego życia. Czas oczekiwania, jeśli się przedłuża, może znacznie obniżać doświadczaną przez chorego jakość życia. Cierpiący z powodu postępującej choroby niewydolnego organu widzą, że uczestniczą w swoistym wyścigu z czasem. Aby odnieść zwycięstwo, musi zostać w porę wykonany udany przeszczep.

Tymczasem wezwanie mojego rozmówcy na przeszczep nastąpiło w chwili, gdy lekarze dawali mu zaledwie siedem do ośmiu miesięcy życia. Była to połowa 2001 roku. Po operacji pozostawał w szpitalu jeszcze przez prawie trzy miesiące, bowiem w piątej dobie po zabiegu jego organizm zareagował ostrą reakcją odrzucania przeszczepu ${ }^{8}$. Potem pojawiły się inne komplikacje zdrowotne, o których Zygmunt sam wspomina po dziesięciu latach:

${ }^{8}$ Odrzucanie przeszczepu może mieć trzy formy: 1. nadostrą (humoralną) - wytwarzają się przeciwciała u biorcy skierowane przeciw głównym grupom krwi i klasie I antygenów zgodności antygenowej; 2. ostrą (komórkową) - to obserwowane jest w pierwszym miesiącu po zabiegu; przewlekłą (duktopeniczną) - występuje w okresie dłuższym niż miesiąc i jest bardzo trudna do oceny mikroskopowej (por. Bardadin, 1998: 49). 
U mnie były powikłania. Trudno je było zdiagnozować. (...) Wreszcie jak zdiagnozowano, to podano leki i w ciągu tygodnia zaraz wyszedłem do domu. Nie schodziła mi żółć i miałem zastój żółci w organizmie.

Gdy już w domu powracał do zdrowia, niestety uaktywnił się wirus zapalenia wątroby typu C. Było to zaledwie siedem miesięcy od daty przeszczepu i:

On jest teraz też cały czas i powoli mi tą nową wątrobę niszczy. I wtedy ją zaatakował.

Mój badany był niepomiernie zmartwiony takim stanem rzeczy, wszak swoją wątrobę stracił właśnie w wyniku niszczącego działania owego wirusa. W związku z tym chciał, żeby podano mu lek interferon ${ }^{9}$. Nie było to proste, ale gdy zjawił się wreszcie na oddziale w szpitalu w celu przyjęcia pierwszej dawki tego specyfiku, okazało się, co zdumiewa mojego rozmówcę do dziś:

Że wyniki mi się o połowę poprawiły. Nie wiem, czy to opatrzność Boża, czy coś, czy organizm mi się tak przestawił. (...) I odwołano podawanie leku. I do tej pory tak się utrzymuje.

Niewątpliwie takie wydarzenia odciskały piętno na doświadczanej wówczas przez Zygmunta jakości życia. Zresztą w tym samym czasie, czyli raptem siedem miesięcy po przeszczepie, miał on również inne problemy zdrowotne. Tym razem mój rozmówca wspominał o cukrzycy, która pojawiła się u niego wskutek stosowania leków immunosupresyjnych. Wszczepienie bowiem do ustroju transplantu alogenicznego (czyli od dawcy, który nie jest identyczny genetycznie z biorcą) wywołuje w układzie odpornościowym biorcy reakcję odrzucania ciała obcego. Ratunkiem dla życia pacjenta jest stosowane leczenie immunosupresyjne mające na celu obniżenie odporności organizmu biorcy ${ }^{10}$. U Zygmunta w tym celu od czasu transplantacji stosowano lek o nazwie handlowej Prograf (substancja czynna takrolimus). Jednym z bardzo często spotykanych u pacjentów niepożądanych następstw zażywania go jest właśnie wzrost stężenia cukru we krwi oraz cukrzyca (Charakterystyka produktu leczniczego, 2011: 94), która pojawiła się u Zygmunta. Mój badany również o tym wiedział, skoro stwierdził:

To wszystko zależy od leków immunosupresyjnych. (...) Jak czytałem ulotkę z tego leku, to aż nie chciałem wierzyć, że tyle jest skutków ubocznych! Na wszystko [może szkodzić - dop. I.C.], ale coś za coś, żeby żyć to trzeba [je zażywać - dop. I.C.].

9 Pegylowany interferon wprowadzony do leczenia w sytuacji zapalenia wątroby typu C HCV skojarzony z innymi lekami (rybawiryną) daje szanse na całkowite wyleczenie - pełne zahamowanie repliki HCV (por. Kowala-Piaskowska, Figlerowicz, Mozer-Lisewska, W. Służewski, 2005: 491).

${ }^{10}$ Biorąc pod uwagę relację łączącą dawcę i biorcę, wyróżnia się jeszcze autoprzeszczepy - które oznaczają w inne miejsce tkanki lub narządu w obrębie jednej osoby; izoprzeszczepy - dokonywane pomiędzy osobami identycznymi genetycznie, czyli bliźniętami jednojajowymi; ksenoprzeszczepy - przeprowadzane pomiędzy dwoma osobnikami różnych gatunków, tu wyróżnia się jeszcze ksenotransplantację zgodną i niezgodną. Wyjątek stanowią izoprzeszczepy, czyli między bliźniakami jednojajowymi. Zabiegi takie odbywają się niemal ze stuprocentowym powodzeniem i chory może obyć się bez zażywania leków immunosupresyjnych, choć są one na ogół podawane (Cinqualbre, Wolf, Ellero, Boudjema, 1993: 20; Thorwald, 2010: 175-198). 
Pewnego dnia, kibicując na stadionie swojej drużynie na meczu piłki nożnej (prowadząc już życie niemal jak osoba niedotknięta tak poważną chorobą), zorientował się, iż niewyraźnie widzi piłkarzy. Pogłębianie się tego stanu tak go zaniepokoiło, że w czasie drugiej połowy meczu opuścił stadion. Zaczął już całkiem tracić wzrok, zanim zostało potwierdzone, iż to właśnie znacznie podwyższony poziom cukru przysparza mu takie dolegliwości. Znowu nastąpiła konieczność hospitalizacji. Kolejne trzy tygodnie trwała kuracja za pomocą pompy insulinowej, zanim poziom cukru we krwi zaczął powoli się obniżać. Przez następne miesiące Zygmunt był zmuszony przyjmować insulinę w zastrzykach, a potem w tabletkach, aż się unormował poziom cukru. Lekarz prowadzący również zmienił Zygmuntowi podstawowy lek immunosupresyjny z Prografu na Neoral (substancja czynna cyklosporyna). Oczywiście ten specyfik również daje skutki niepożądane. Tym razem bowiem mój badany zaczął uskarżać się na skoki ciśnienia tętniczego:

Chyba po półtora roku czasu miałem w domu krwotok. Dobrze się okazało, (...) że poszedł mi gardłem. Pogotowie, jak przyjechało, to miałem ciśnienie 240/160. Leżałem w szpitalu i o 5 rano pomimo tego, że dostawałem leki zakrzepowe, to dostałem znowu wylewu. Ale jakoś zatrzymali mi ten krwotok. Na drugi dzień robili mi bronchoskopię, fiberoskopię, i okazało się, że wszystko poszło do oskrzeli do płuca i wysłali wycinki do Białegostoku i na własną prośbę wypisałem się ze szpitala za dwa dni. I zadzwoniłem do Instytutu Transplantologii.

Dalszą kurację Zygmunt odbywał w szpitalu klinicznym, gdzie powtórzono mu różne badania i ustalono terapię. Do domu wrócił po półtora miesiąca z, jak sam mówił: ciśnieniem książkowym. Pomiędzy tymi dwiema hospitalizacjami spowodowanymi niepożądanymi skutkami leków immunosupresyjnych w egzystencji mojego rozmówcy zdarzył się kolejny epizod odrzucania przeszczepu. Było to półtora roku po zabiegu transplantacji. Sam badany wówczas nie odczuwał żadnych nieprawidłowości. Dopiero pięciokrotnie podwyższone wyniki wątrobowe ALAT (aminotransferaza alaninowa) i AspAT (aminotransferaza asparaginianowa) wykazywały toczący się w organizmie biorcy niebezpieczny proces:

Pobrano mi wycinek w biopsji wątroby i podano mi leki. I po półtora miesiąca, [które - dop. I.C.] spędziłem w szpitalu i wróciłem do domu.

Zarówno Zygmunt, jak i inni biorcy narządu zdają sobie sprawę, iż w każdej chwili, nawet po latach od zabiegu transplantacji, ich organizm może zacząć odrzucać przeszczep i to w wyniku nawet błahej, zdawałoby się, infekcji. Są oni świadomi kruchości swojej egzystencji. Dlatego też pacjenci znajdują się pod stałą opieką lekarzy transplantologów, jeżdżąc na wizyty kontrolne zazwyczaj cztery razy do roku (to liczba przy optymalnym stanie zdrowia pacjenta, gdy zachodzi potrzeba, co oczywiste, zwiększa się ich częstotliwość). Pacjenci są zwykle w posiadaniu numerów telefonów komórkowych do swoich lekarzy prowa- 
dzących. Zygmunt od przeszczepu znajduje się pod opieką tego samego lekarza, z czego jest bardzo zadowolony, co wyrażają następujące jego sformułowania:

Ja z nim rozmawiam na stopie koleżeńskiej, jak z tobą [zwraca się do mnie - badacza]. Przychodzę do niego, witam się z nim. Pytam się, co tam w domu u niego słychać, jak tam dzieci jego - jak kolega z kolegą tak rozmawiam. On też się mnie pyta, jak rodzina i wywiad ze mną przeprowadza i w międzyczasie patrzy, jak tam wyniki [badań - dop. I.C.] i jakie zalecenia wydać. A nieraz i w zastępstwie [gdy mój lekarz jest nieobecny - dop. I.C.], to też mam bardzo dobry kontakt $\mathrm{z}$ innymi lekarzami.

Jedyne zastrzeżenia do opieki nad chorymi po przeszczepie mój rozmówca ma do rozwiązań komunikacyjnych ze swojego miasta do stolicy oraz do organizacji rejestracji chorych w przychodni. Rejestracja telefoniczna pacjentów na wizyty do lekarzy zaczyna się dopiero o godzinie 8:30. Gdy uda mu się dodzwonić do przychodni (co również nie jest sprawą łatwą), okazuje się, że zostaje zapisany już nawet jako dwunasty w kolejce przyjmowania pacjentów. Konsekwencje tego stanu rzeczy bardzo opóźniają godzinę powrotu Zygmunta do domu, jak sam wspomina:

Lekarz przyjmuje od godziny 13, a nieraz się spóźni, to wchodziłem do gabinetu około 15, 15:30. A pociąg miałem około 15 , to na niego nie zdążałem. Teraz jest pociąg około 17 , to $\mathrm{w}$ domu jestem o 22 z groszami. Z tym, że mam serdecznego kolegę w Warszawie, który jest też po przeszczepie wątroby. To jak on jest nieraz w [mojej miejscowości - dop. I.C.], to mnie zabiera. Nocuję wówczas u niego [przyjeżdżając dzień wcześniej - dop. I.C.] i następnego dnia mnie podwozi pod przychodnię.

Zygmunt docenia wartość pomocy przyjaciół. Sam zresztą jest również niezmiernie uczynny. Warto w tym miejscu przytoczyć następującą historię. Przed kilku laty wspominany kolega w bardzo złym stanie zdrowia, który bez należytej opieki medycznej i właściwego leczenia był hospitalizowany w jednym ze szpitali w Warszawie. Mój badany nie znał go jeszcze wówczas osobiście, a jedynie dowiedział się o nim w prywatnych rozmowach. Nie zważając jednak na to, że nic prócz nazwiska owego cierpiącego nie wie, ani na fakt, że słabo zna stolicę - postanowił spotkać się z nim. Odnalazł szpital, oddział i leżącego na łóżku szpitalnym chorego zakażonego wirusem zapalenia wątroby typu C. Zdumionemu odwiedzinami pacjentowi Zygmunt opowiedział o przebiegu swojego leczenia, jak się poprawiło jego zdrowie po przeszczepie wątroby. Swoją wizytą dał wycieńczonemu postępującym niedomaganiem wątroby nadzieję na uratowanie życia i poprawę jego jakości. Pomoc była na tyle owocna, że aktualnie, jak sam Zygmunt wspominał, ów kolega żyje, będąc kilka lat po przeszczepie wątroby. Mój badany wykazuje postawę życzliwości po dziś dzień i niejednokrotnie, gdy zachodzi potrzeba, rozmawia telefonicznie lub, będąc na wizycie kontrolnej w Warszawie, odwiedza osoby na oddziale szpitalnym, o których się wcześniej dowie, że potrzebują wsparcia. W tym przykładzie uwidacznia się wzajemna życzliwość, jaką biorcy organu (w znakomitej większości) okazują innym, oczekującym na transplantację oraz 
solidaryzowanie się z tymi, którzy już są po udanej transplantacji. Jak zauważa A. Drabanek, należy kształtować w sobie samym postawę życzliwości wobec „tych, którym można przynieść doraźną pomoc z tej racji, iż są aktualnie od nas słabsi” (Drabarek, 2004: 149).

Tymczasem 2005 r. przyniósł następne przykre niespodzianki obniżające przeżywaną jakość życia przez Zygmunta. Mojemu rozmówcy bowiem stale przeszkadzało coś w gardle przy przełykaniu. Próbował odchrząkiwać, ale bez rezultatu. Po wstępnej, błędnej diagnozie wskazującej, że jest to zwykła torbiel do usunięcia, okazało się jednak, że przyczyną niedogodności jest nowotwór. Badany opowiadał o tym niezmiernie emocjonalnie:

To był chyba najgorszy dla mnie dzień - 22 grudnia 2005 roku. Zadzwonił do mnie lekarz i kazał zaraz przyjeżdżać, że to nie jest żadna torbiel, tylko chłoniak, i kazał mi przyjechać na następny dzień. Odmówiłem mu, bo powiedziałem, że przez święta nic mi nie będą robić. Całe święta miałem takie zmarnowane! Myślałem tylko o tej swojej chorobie i po świętach nie pojechałem, bo pomyślałem sobie, że do nowego roku też nic nie będą mi robić.

Po Nowym Roku mój rozmówca pojechał na operację usunięcia nowotworu. W szpitalu pozostawał jeszcze przez miesiąc, bowiem, jak się okazało, chłoniak ten miał być już przerzutem. Szukano więc ogniska zapalnego. Po wielu inwazyjnych badaniach stwierdzono jednak, iż to, co usunięto, było ogniskiem zapalnym samym w sobie:

Ale konsylium trzech profesorów (...) napisało, że to jest od leków immunosupresyjnych i żeby je ograniczyć. (...) I teraz biorę minimalne dawki leków immunosupresyjnych.

Około sześć lat po przeszczepie (mój badany dokładnie już nie pamiętał, kiedy to się zdarzyło) Zygmunt wybrał się na wycieczkę rowerową z wnukiem. Przy zjeżdżaniu z niewielkiej górki tak niefortunnie się przewrócił, że uderzył głową o ziemię i na 10-15 sekund stracił przytomność. Pieszo wracał prawie dwa kilometry do domu, prowadząc rower. Następnie, również pieszo, udał się na pogotowie po pomoc. Po wszystkich badaniach szpitalnych (najpierw leżał w swojej miejscowości, później w Warszawie) okazało się, że złamał rękę i miał wstrząs mózgu.

W narracji mojego badanego wielokrotnie powtarzają się długotrwałe leczenia szpitalne. Oczywiście, nie jest tak u wszystkich osób żyjących z przeszczepionym narządem. Niemniej takie jest akurat doświadczenie Zygmunta, który zauważa swoistą wyjątkowość swojej biografii:

Cały czas, jak nie jedno, to drugie! I pod górkę i pod górkę! Boże kochany! Nie wiem, co jeszcze mnie w życiu czeka! (...) Tak się zastanawiałem w swoim życiu, że (...) ja już jako młody dzieciak, od 4 i pół roku zacząłem chorować i tak cały czas. Co wejdę na górkę i znowu w dół. [teraz już głośniej i z naciskiem] Pomimo tego wszystkiego wyszedłem!

Widać, jak mój rozmówca nie poddaje się zwątpieniu. A trzeba przyznać, że oprócz własnych dolegliwości doświadczył i innych cierpień. Wiele lat temu na 
jego oczach w wypadku komunikacyjnym zginęła kilkuletnia córka, co było poważnym ciosem dla niego samego, jak i jego małżeństwa. Jednak wraz z małżonką są razem i są dla siebie wzajemnie oparciem w każdej trudnej chwili. Kilka lat temu Zygmuntowi przyszło zmagać się w nowej dla niego roli - jako bliski osoby chorej (nie sam jako pacjent), to znaczy w chwili choroby nowotworowej małżonki. Swoje przeżycia i wartość, jaką ma dla niego relacja z żoną, można odczytać w następujących słowach mojego rozmówcy:

Co ja przeżyłem sam, [podnosi głos] jak żona zachorowała, to tylko ja wiem! (...) Jakby mi żona odeszła, to zostałbym sam. (...) Ogólnie mogę liczyć tylko na żonę, na nikogo więcej. Choć sam staram się rozwiązywać problemy. Jedyne oparcie, to powiem szczerze, mam tylko w żonie! Choć się kłócimy czasem. (...) Człowiek się żenił, brał ślub na dobre i na złe. Teraz trzeba to wypełniać.

Mój badany swojego sensu życia teraz po latach upatruje, jak sam mówi, w tym, by dożyć spokojnie do emerytury, ale i by nie być dla nikogo ciężarem, którym trzeba się będzie opiekować. Zdaje sobie sprawę z upływającego czasu i stwierdza, nieco z żalem:

Swoje w życiu już przeszedłem, przeżyłem. Może jeszcze zostało mi z 20 lat życia po tym przeszczepie. (...) Mam już 56 lat, jak się do tej pory domu nie dorobiłem, to się już nie dorobię! Mam ten wirus HCV i on cały czas tę wątrobę niszczy.

W innym momencie naszej rozmowy Zygmunt opowiedział, co uważa za swój sukces życiowy. Jest to długa wypowiedź, ale wydaje się niezmiernie istotne, by została przytoczona w tak dużym fragmencie, bowiem znacząco obrazuje sens i nastawienie do życia w ogóle mojego rozmówcy:

Sukcesem to byłoby to, że ja przez swoją upartość się tego przeszczepu doczekałem. Bo nikt mi nie wierzył, że będzie przeszczep (...) A ja cały czas żyłem nadzieją. [krótka przerwa] Że tego przeszczepu doczekałem, ten przeszczep przeszedłem i że tyle miałem powikłań po przeszczepie (...) i dalej to wszystko przechodzę. Dla mnie to jest sukces! [mówi z naciskiem] Że ja się nie załamuję, że do głowy nie biorę, że tam, że coś będzie jeszcze gorzej! Nie wiem, co będzie, ale że jakoś tak to wszystko przeżywam, jakoś daję sobie radę. (...) to mi się wydaje ten mój sukces, że ja mogę to przetrwać, że nie załamuję się tam. Ta moja wiara, że co będzie to będzie, kurczę, jakoś! I tak sobie nieraz pomyślę: [spokojniej i zaczyna bardzo wolno mówić] ludzie zdrowsi, Boże kochany, przyjeżdżali do szpitala do mnie odwiedzać z rodziny i bardzo bliscy i koledzy i sąsiedzi z wioski. I tak patrzę: tego nie ma, tego nie ma, tych nie ma, tych nie ma. Ci ludzie wszyscy poodchodzili, a ja żyję! I po takim przeszczepie [głośniej], po takich perturbacjach, po takich operacjach! I człowiek daje radę i normalnie funkcjonuje i pracuje. Jak to komuś mówię, to: - Panie! - mówi - Pan chyba wodę lejesz - mówi. Ja: Nie będę się przy panu rozbierał, na co ja chorowałem. Chcesz pan wierz. Chcesz pan, nie wierz - mówię. No to mówi: - Panie, pan jest stalowy człowiek! Także [zawiesza głos] to uważam: mój sukces, nie? A co będzie dalej, to nie wiem, nie? [wszystkie podkreślenia pogrubionym drukiem - I.C.].

Wyraźnie uwidacznia się w tejże wypowiedzi mojego rozmówcy jego szukanie/widzenie własnych osiągnięć poza dobrami materialnymi. Nadzieja, o której 
z taką stanowczością mówi, stanowi niewątpliwie siłę do przetrwania tak licznych sytuacji niepewnego losu spowodowanych problemami zdrowotnymi i życiowymi. Zygmunt odczuwa wdzięczność za dar, jakim jest swoista dodatkowa „porcja życia”. Pamięta, jak wielką zasługę w tym względzie ma zmarły dawca oraz jego najbliżsi, którzy przyzwolili na pobranie narządu ze zwłok bliskiego im zmarłego. Mój rozmówca otrzymał organ pobrany od osoby zmarłej, która wcześniej (będąc jeszcze żywą) nie wyraziła sprzeciwu, podpisując specjalny formularz w Centralnym Rejestrze Sprzeciwów (CRS), ani, zgodnie z ówczesną ustawą z 1995 roku" ${ }^{11}$, nie zastrzegła tego pisemnie opatrując własnym podpisem, jak również nie sprzeciwiała się temu w formie ustnej w obecności dwóch świadków. W naszym kraju obowiązuje bowiem tzw. zgoda domniemana (inaczej: zarejestrowany sprzeciw), w myśl której do pobrania ze zwłok komórek, tkanek i narządów może dojść wtedy, gdy za życia zmarły nie wyrazi sprzeciwu na taki stan rzeczy ${ }^{12}$. Zgoda domniemana nie jest stosowana w przypadku osób małoletnich, choć młodzież od 16 roku życia może już sprzeciw wyrazić samodzielnie ${ }^{13}$. Biorcy po udanej transplantacji w poczuciu obdarowania dodatkową porcją życia z nową jej jakością wyrażają częstokroć starania, by okazywać swoją wdzięczność. Mój rozmówca również to czyni:

Po przeszczepie, chyba cztery lata, ze swoją wnuczką poszedłem na pielgrzymkę pieszą. Chciałem podziękować Matce Bożej, że doczekałem przeszczepu, i za tę osobę [która była dawcą dop. I.C.], bo nie wiem do dzisiaj, kto jest tą osobą. [Wiem - dop. I.C.] tylko tyle że była to młoda dziewczyna. Też w tej intencji poszedłem, między innymi, podziękować Jemu [Bogu - dop. I.C.], za nią [dawczynię - dop. I.C.] się pomodlić, nie?

Warto w tym miejscu wspomnieć, iż w Polsce ani biorca organu, ani rodzina zmarłego dawcy się nie znają. Dwojako jest to odbierane przez same osoby żyjące dzięki wszczepionemu organowi. Niektórzy pragną się dowiedzieć, kim był i jak żył ich dawca, chcą też poznać jego najbliższych, by podziękować za wyrażenie akceptacji na eksplantację organów. Inni zaś nie czują potrzeby spotkania, choć nie zapominają o duszy zmarłego dawcy ani jego rodzinie w swoich modlitwach ${ }^{14}$. Tak jest i w przypadku mojego rozmówcy.

${ }^{11}$ Była to Ustawa z dnia 26 października 1995 r. o pobieraniu i przeszczepianiu komórek, tkanek i narządów, Dz.U. nr 138, poz. 622. W przeciągu ostatnich lat było wprowadzanych kilka zmian: Ustawa z dnia 1 lipca 2005 r. o pobieraniu, przechowywaniu i przeszczepianiu komórek, tkanek i narzadów, Dz.U. nr 169, poz. 1411; oraz Ustawa z dnia 17 lipca 2009 r. o zmianie ustawy o pobieraniu, przechowywaniu i przeszczepianiu komórek, tkanek i narządów oraz o zmianie ustawy - Przepisy wprowadzajace Kodeks karny, Dz.U. nr 141, poz.1149.

12 Por. Ustawa $z$ dnia 1 lipca 2005 r...., Art. 5.1.

13 Tamże, Art. 5.2 i 5.3.

14 Więcej na temat stanowiska osób badanych przeze mnie w tejże kwestii w: Cymerman, 2007 oraz innych artykułach, których jestem autorem: Cymerman, 2002a: 191-196; Cymerman, 2002b: 127-143; Cymerman, 2002c: 291-303; Cymerman, 2003b: 45-56; Cymerman, 2006: 263-276. 
No i jestem katolikiem. Dużo, codziennie Pana Boga proszę o swoje zdrowie, dla swojej rodziny. I jakoś Pan Bóg mnie wspiera w tych nieraz trudnych chwilach, dobrych czy złych. Nie to, że się mi problemy wszystkie rozwiążą, ale po jakimś tam czasie, za tydzień, za dwa, za trzy, jakoś tak wszystko się rozwiąże, jakoś się ułoży. I jakoś tak się ciągnie, nie.

Po dziesięciu latach od naszej pierwszej rozmowy w biografii Zygmunta wiele się zdążyło wydarzyć (nieco obrazuje to dotychczasowy opis). Dużo też zaszło zmian w nim samym. Mój badany zauważył, iż w swojej codzienności stał się wolniejszy, częściej też zdarza mu się zapomnieć różne proste rzeczy, dlatego nie podejmuje się już raczej działać spontanicznie, woli planować swój dzień i następne. W innym bowiem przypadku, jak opowiada:

Zaraz zapominam i już nie pamiętam, gdzie ja klucze położyłem czy coś. (...) I wzrok mi siadł. Zarysy widzę, ale tak szczegółowo, jak mam coś zrobić, przykręcić, to są problemy. I wtedy się staję bardziej nerwowy, że ojeju, nie mogę czegoś zrobić i, że wnuczka muszę prosić o pomoc. (...) To taki człowiek jest bardziej nadpobudliwy, może dlatego, że wszyscy krzyczą na mnie, że ja głośno mówię. A mi się wydaje, że jak po cichu mówię, to nikt mnie nie słyszy. I żona mówiła, że się zmieniłem, że bardziej oszczędny jestem. Ja bynajmniej tego nie widzę, ale może?

Przyczyn takich zmian w swojej osobowości, sposobie bycia Zygmunt upatruje kilka. Widzi oczywisty upływający czas, który niewątpliwie wpływa na pogorszenie się funkcjonowania organizmu. Dostrzega niepożądane skutki leków immunosupresyjnych, ale także swoich zmian doszukuje się w przeszczepie jako takim. Na podstawie oglądanych przez siebie programów edukacyjnych emitowanych przez stację Discovery zaczyna się zastanawiać nad wpływem osobowości dawcy przeszczepionego organu na jego zmiany. Dodatkowo również mówi, iż podczas dwunastogodzinnej operacji zostało mu przetoczone bardzo wiele krwi, stąd Zygmunt przypuszcza, że ten fakt mógł również zaważyć na jego obecny sposób patrzenia na świat i sposób życia. Ten aspekt, o którym wspomina mój rozmówca, jest jednak nadal sferą niezbadaną przez badaczy.

Obecnie Zygmunt nadal pracuje zawodowo, choć już na innym stanowisku z powodu restrukturyzacji firmy zatrudniającej go. Mniej więcej co kwartał zjawia się u swojego lekarza prowadzącego, by sprawdzić stan swojego zdrowia. Angażuje się w pomoc informacyjną i nie tylko osobom cierpiącym, a podobnie jak on kiedyś, czekających na przeszczep wątroby. Mieszka z żoną. Od kilku miesięcy przygotowuje się do nowej roli - pradziadka. Niebawem bowiem nim zostanie.

\section{Nowe obszary zainteresowań pedagogiki}

Jak zostało na wstępie zaznaczone, jest zasadne by zagadnienia związane $\mathrm{z}$ tematyką transplantacyjną znalazły się w kręgach zainteresowań pedagogów. Pierwszy powód, jaki się nasuwa, to cały obszar przeżyć ludzkich w obrębie antroposfery 
aksjologicznej, których doświadczają osoby przed- i po przeszczepie narządu. Zagadnienia te, co było wspominane na początku tekstu, nie mogą pozostawać poza kręgiem refleksji badawczych oraz działań pedagogicznych, wszak osoby w każdym wieku są podmiotami pedagogicznymi. Nie powinny być one, co oczywiste, pozbawiane opieki pedagogicznej szczególnie wówczas, gdy cierpią i faktycznie potrzebują pomocy oddanych i bezinteresownych ludzi. Chorzy żyjący dzięki przeszczepionemu narządowi muszą się uczyć od nowa konstruować swoją codzienność ${ }^{15}$. W związku z reorganizacją dotychczasowych nawyków niejednokrotnie ulega ewoluowaniu lub nawet rewolucji świat aksjologicznych zagadnień.

Warto zwrócić uwagę na fakt, iż człowiek przebywa wśród innych ludzi, a w zależności od etapu życia i okoliczności w większym lub mniejszym stopniu egzystuje właśnie dzięki tym, których spotyka na swojej drodze. Doświadczenie poważnego schorzenia wraz z wszystkimi konsekwencjami to czas szczególny w egzystencji istoty ludzkiej, dający jej możliwość odczucia/odczuwania własnej ograniczoności i niewystarczalności, a zarazem dobra wynikającego $\mathrm{z}$ faktu współbycia $z$ innymi. Oto bowiem niewydolność danego organu może mieć postać o charakterze piorunującym i wówczas niemal z dnia na dzień człowiek musi dokonać całkowitej przemiany dotychczasowego swojej codzienności. Zdarza się jednak również i tak, iż zanikanie prawidłowej funkcji narządu jest stopniowe, niekiedy rozciąga się nawet na lata ${ }^{16}$. Niezależnie jednak od przebiegu okresu postępu niewydolności organu każda $\mathrm{z}$ osób ${ }^{17}$ dotąd ciesząca się (i nie zwracająca zbytnio na to uwagi) zwyczajną swobodą w podejmowaniu decyzji, szczególnie w sprawach podstawowych (jak choćby co i kiedy zjeść, jak się ubrać) - traci do tego prawo w wyniku zaniku wystarczającej ku temu zdolności jej organizmu. W tym też kontekście wyłaniają się następne argumenty za niebagatelizowaniem tematyki transplantacji organów przez przedstawicieli nauk pedagogicznych. Są to mianowicie aspekty religijne i etyczne, bowiem dylematy mają na przykład biorcy organów zarówno jeśli chodzi o dawstwo żywe, jak i przeszczepy pobierane ze zwłok. Stąd warto znać wykładnię wyznawanej przez siebie religii, by czuć się w zgodzie z własnym sumieniem ${ }^{18}$. Wątpliwości etyczne ponadto, które mogą się rodzić u osoby chorej, obejmować mogą pytania typu: czy jest moralnie zasadne dla ratowania własnego życia i zdrowia prosić kogoś bliskiego ${ }^{19}$, by ten

${ }^{15} \mathrm{O}$ tym, jak proces ten przebiegał w przypadku kilkunastu osób przeze mnie badanych żyjących z przeszczepioną wątrobą lub nerką pisałam między innymi w: Cymerman, 2003a.

${ }^{16}$ Szerzej doświadczaniu jakości życia przed oraz już po zabiegu transplantacji nerki lub wątroby pisałam w: Cymerman, 2003a.

${ }_{17}$ Zazwyczaj każda, bowiem może być również sytuacja, gdy ktoś od urodzenia cierpi z powodu choroby nerek, bądź wątroby.

${ }^{18}$ O stanowisku niektórych, wybranych religii pisałam w: Cymerman, 2003a.

19 W myśl polskiego ustawodawstwa przede wszystkim osoby spokrewnione z chorym czekającym na transplantację organu mogą darować mu nerkę bądź fragment wątroby. O tym, czy poten- 
narażał swoje zdrowie i życie (wszak każdy zabieg chirurgiczny niesie ze sobą choćby minimalne ryzyko) dla niej? Wszakże „nikt nie ma obowiązku darowania swoich organów lub tkanek, nikt też nie może zgłaszać roszczeń prawnych do organów drugiego człowieka, żywego, czy zmarłego. Jedynie właściwą formą oddania organu jest forma wolnego daru" (Morciniec, 2007: 468). Jednakże nawet gdy dawca żywy jest chętny do obdarowania chorego swoim narządem, to pacjent czekający na zabieg może się obawiać sytuacji, w której mimo wykonanej transplantacji przeszczep zostanie odrzucony przez organizm biorcy. Wówczas poczucie zmarnowania daru przy tak poważnym nakładzie ze strony dawcy mogłoby nękać chorego i apriorycznie zniechęcać nawet do podejmowania tematu o dawstwie żywym. Jednakże warto w tym miejscu zaznaczyć, iż zazwyczaj dawstwo żywe (ex vivo) daje lepsze wyniki u chorych z racji możliwości doboru optymalnego zarówno organu, jak i terminu na transplantację, a także krótkiego czasu niedokrwienia przeszczepianego narządu.

Dawstwo ex mortuo (ze zwłok) również nie pozostaje bez dylematów etycznych. „W tym przypadku kolidują ze sobą dwa ważne moralne zobowiązania: zabezpieczenie prawa do wolnego dysponowania własnym ciałem (także po śmierci) oraz fundamentalna solidarność międzyludzka, zobowiązująca do ratowania życia chorego człowieka przez pośmiertne oddanie organów” (Morciniec, 2007: 470). Zasada solidarności międzyludzkiej skoncentrowana jest na tym, aby nikt, „kto nie potrafi sobie sam pomóc, nie był pozostawiony przez innych w jakiejś totalnej samotności, na marginesie" (Ross, 2003: 171). Poza tym bardzo ważną kwestią jest sama definicja śmierci i śmierci mózgowej, która ewoluuje wraz z postępem nauk medycznych ${ }^{20}$.

Warto zauważyć, iż dylematy o rozmaitym podłożu dotyczą zarówno osób z kręgów medycznych, jak i „zwykłych” biorców i dawców oraz ich bliskich. Wobec każdego z nich bowiem w jakimś momencie zachodzi interakcja. Oczywiście nie jest to bezpośrednie spotkanie, gdy mówimy o dawcy zmarłym, jego bliskich wraz z biorcą. Niemniej jednak jest to wzajemne oddziaływanie, a w przypadku

\footnotetext{
cjalny niespokrewniony dawca żywy może nim zostać, decyduje sąd. Chodzi głównie o wykluczenie sytuacji, w której de facto nie ma mowy o darze, lecz o transakcji handlowej między biorcą i dawcą. To jest również niedopuszczalne w Polsce. Ustawa z dnia 1 lipca 2005 r. o pobieraniu..., Art. 12 i 13; oraz Ustawa z dnia 17 lipca 2009 r. o zmianie ustawy o pobieraniu..., Art. 41.1 i 41.2.

${ }^{20}$ Nadal należy mieć nadzieję na jej kolejne. Oznaczałoby to, iż coraz lepiej potrafimy z jednej strony określać koniec życia człowieka, z drugiej zaś być może okazałoby się, że byłoby możliwe przywracanie funkcji mózgowych u tych, którym do tej pory stan wiedzy medycznej nie dawał żadnych szans). Przy okazji pojawiają się inne zagadnienia etyczne związane z transplantacją narządów, jak np. alokacja narządów, handel organami, transplantacja a kanibalizm oraz wspomniana śmierć mózgowa. Zarys tych dylematów zawarłam w książce: Cymerman, 2007. Jednak śmierć mózgowa - jej definicja budzi stale wiele niepokojów wśród niektórych. Przykładem jest książka: Norkowski, 2011.
} 
dawcy zmarłego (choć niejednokrotnie jeszcze w Polsce nieuświadomiony z braku wystarczającej edukacji w tym względzie) jest to „życiodajny” dar dla chorego biorcy. Osoby zaś ze środowiska medycznego wchodzą w relacje z każdym z podmiotów: biorcą, dawcą oraz ich bliskimi. Ważna jawi się tutaj wysoka jakość tychże relacji, aby towarzyszyła im postawa wzajemnej życzliwości, poszanowania godności, a także świadomość uczestnictwa. Ta ostatnia określa „sposób odnoszenia się do innych ludzi ze względu na działanie wspólnie z innymi oraz uzgadniania własnych form działania z wyborami innych i z własną godnością?21. I tu wyłania się cały obszar dla niezbędnej działalności pedagogicznej: wobec środowiska lekarskiego oraz chorych i ich rodzin. Pola zainteresowań możliwych dla pedagogów zawarłam w schemacie 1.

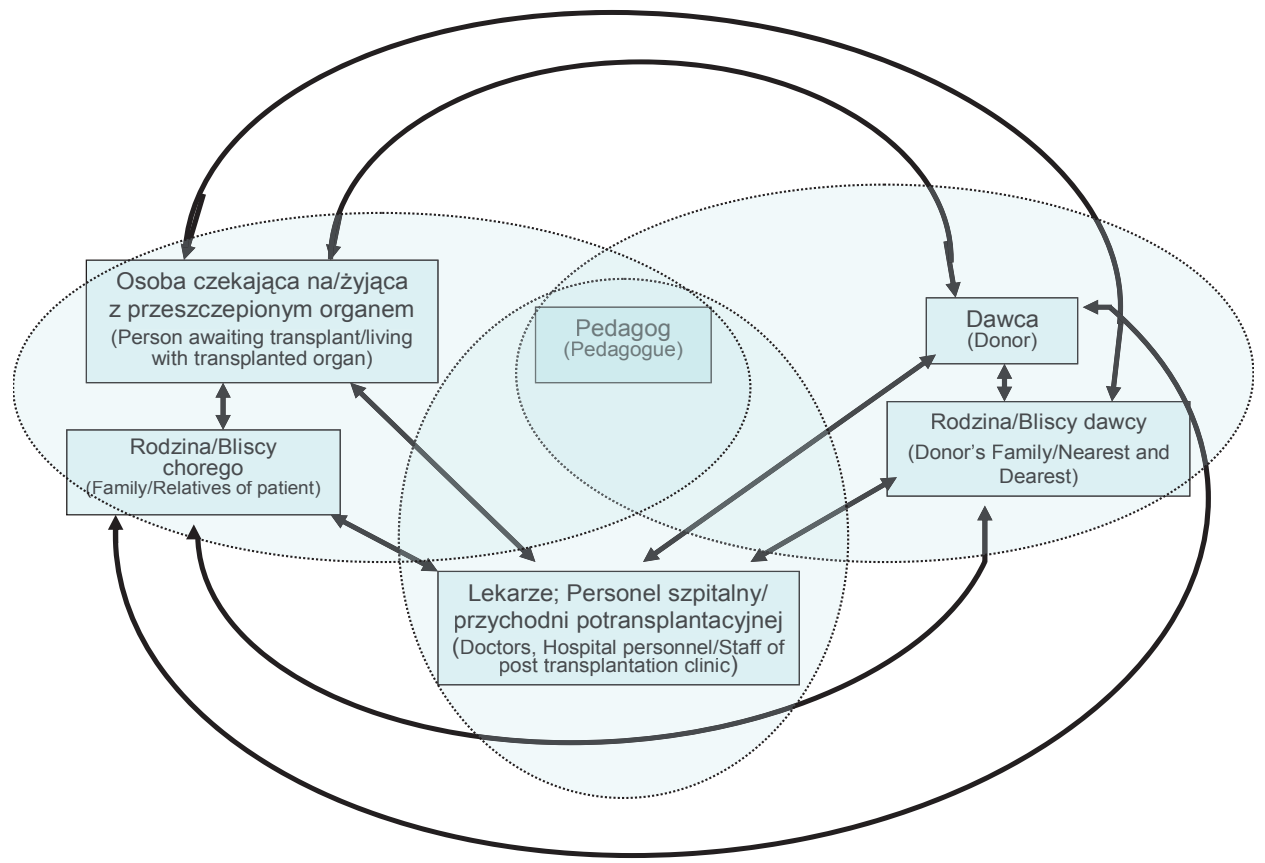

Schemat 1. Obszary zainteresowań pedagogicznych związanych z transplantacją organów

Źródło: koncepcja własna

Schemat przedstawia pola możliwych badań oraz działań pedagogicznych $\mathrm{w}$ relacjach osób zaangażowanych w transplantację organów. W niniejszych relacjach występuje sześć rodzajów podmiotów: Dawca, jego Rodzina/Najbliżsi, Osoba czekająca na/żyjąca z przeszczepionym narządem, Rodzina/Bliscy chorego, Lekarze; Personel szpitalny/przychodni potransplantacyjnej oraz Pedagog.

21 Jan Paweł II, Redemptor hominis, nr 17, za: Szymczyk, 2004: 76. 
Oddziaływanie edukacyjno-wychowawcze podmiotu, jakim jest pedagog, rozpościerałoby się zatem w trzech obszarach antroposfery, które obejmowałyby: dawcę i jego bliskich; drugi obszar dotyczyłby biorcę i jego bliskich; zaś trzeci zawierałby w sobie osoby związane ze środowiskiem medycznym, biorące udział w przygotowywaniu, $w$ trakcie i opiece już po transplantacji narządu nad pacjentami. Każde z tych pól ma swoją część oddzielną, zarezerwowaną tylko dla danej grupy ludzi.

Specyfika pracy pedagogicznej w polu zawierającym osobę dawcy oraz jego bliskich dotyczy przede wszystkim edukacji transplantacyjnej. Obejmuje ona zakres wiedzy o aspektach prawnych, etycznych i religijnych oraz oczywiście o aktualnych osiągnięciach medycyny w tym względzie. Istotą jest zatem przede wszystkim uczenie, informowanie (jednak bez agitacji). Ważne jest, aby każdy autonomicznie, na podstawie rzetelnych danych mógł podjąć decyzję odnośnie wyrażenia zgody bądź sprzeciwu wobec eksplantacji własnych organów po śmierci lub w szczególnych sytuacjach - jako dawca żywy (na przykład nerka, czy fragment wątroby). Znajomość choćby na przykład rozwiązań prawnych obowiązujących w naszym państwie $\mathrm{w}$ zakresie omawianej problematyki jest niezbędna do tego, by wiedzieć, jako obywatel Rzeczpospolitej, w jakim zakresie mam prawo rozporządzać swoimi narządami pośmiertnie. Aby się zgodzić na coś lub nie, należy najpierw dobrze poznać przedmiot, który stanowi dylemat do rozstrzygnięcia. I w tym mają pomóc działania pedagogiczne. W zasadzie tożsame byłyby działania pedagogiczne skierowane do rodziny dawcy, bowiem nie znając przyszłych zdarzeń, nikt $\mathrm{z}$ nas nie wie, w jakiej roli może się kiedyś znaleźć: dawcy, biorcy, czy kogoś bliskiego tych osób. Ponadto warto podkreślać rolę bliskich zmarłego dawcy, którzy potwierdzili w odpowiednim momencie (po stwierdzeniu śmierci mózgowej) jego pozytywny stosunek do przeszczepów lub, w imię solidarności międzyludzkiej, uznali, że ich bliski życzyłby sobie tego, gdyby wcześniej cokolwiek wiedział na temat transplantacji (tak jest w sytuacji, gdy zmarły nie zostawił żadnych dyspozycji w tej kwestii).

Drugi obszar eksploracji oraz działań pedagogicznych jest usytuowany z lewej strony schematu, czyli obejmuje osobę chorego czekającego na jedyną szansę uratowania mu zdrowia i życia poprzez przeszczep organu, oraz tego, który już jest po tym zabiegu wraz ze swoimi bliskimi. Tutaj istotne są, podobnie jak w pierwszym polu, wcześniejsze (przed zachorowaniem jeszcze) działania edukacyjne, by pacjent był zaznajomiony z tematyką i nie uważał przeszczepu za wyrok śmierci. Oprócz tego wydaje się również ważne samo towarzyszenie choremu, jego bliskim. Swoistą pomocą mogłoby być wówczas współbycie w procesie ewoluowania świata wartości tych podmiotów pedagogicznych. Zmiany degradujące ciało osoby cierpiącej z powodu niewydolności organu powodują coraz większą zależność od innych. To niewątpliwie nie jest łatwe, zwłaszcza dla osoby dorosłej, dotąd odpo- 
wiedzialnej nie tylko za siebie samego, ale i na przykład za rodzinę. Bliscy osoby chorej są właśnie tymi, którzy tę opiekę sprawują na co dzień i doświadczają jej skutków. Najważniejszy jednak okazuje się fakt, iż w tych schorzeniach niezbędny w leczeniu jest narząd pobrany od drugiego człowieka. Zatem liczyć trzeba wyłącznie na życzliwość drugiego człowieka. Jest to bogaty obszar do eksploracji w zakresie zagadnień pedagogicznych.

Obszar trzeci, zarysowany elipsą umieszczoną po środku schematu, stanowi pole działań pedagogicznych wobec środowiska medycznego oraz osób związanych z opieką okołoprzeszczepową (na przykład zatrudnieni w rejestracji przychodni sprawującej opiekę nad chorymi po transplantacji). Znamienny jest tu kontakt pacjenta z lekarzem czy osobą zatrudnioną w placówkach opieki zdrowotnej. Aspektem najważniejszym wydaje się być, wspominana wcześniej, właściwie wysoka jakość owych spotkań z chorym. Osiągnięcie takiego poziomu zależy jednak od tego, czy pracownik służby zdrowia dostrzega w pacjencie, w spotkaniu z nim wartość samą w sobie. Chodzi tu o szacunek dla drugiego człowieka, „pochylenie się" nad cierpiącym przez okazywanie zwykłej, ludzkiej życzliwości. Aby tak patrzeć na drugiego człowieka, niezbędne jest odpowiednie wychowanie z lat młodzieńczych, ale w późniejszym wieku również możliwa jest zmiana systemu wartości (przykładem są osoby chore, u których priorytety w systemie wartości zazwyczaj ewoluują).

Elipsy wyznaczające pola obszarów badawczych i działalności pedagogicznej nie są obrysowane linią ciągłą, lecz przerywaną. Obrazuje to wzajemne przenikanie się, nachodzenie na siebie zawartości pozostałych pól. Wszakże każdy pełni wiele różnych funkcji w swoim życiu, a zdarzyć się może na przykład, iż ktoś z personelu medycznego staje się biorcą organu lub rodziną dawcy. Pomiędzy wszystkimi podmiotami (oprócz powiązań z pedagogiem wyznaczonych przez pola) narysowane są dwustronne strzałki. Symbolizują one wzajemne oddziaływanie i zależności pomiędzy nimi. Nieprzypadkowe są zakrzywione linie łączące biorcę, jego najbliższych z dawcą i jego rodziną. Owo zakrzywienie ma symbolizować relację, która zaistniała $\mathrm{z}$ racji dokonanego przeszczepu, jednak osoby osobiście się nie znają (mowa o transplantacji ex mortuo). Biorcy są wdzięczni dawcy za nową porcję życia dawcy ${ }^{22}$, zaś ich rodziny (biorcy oraz dawcy) są świadome swojego istnienia i na swój sposób starają się o sobie pamiętać (na przykład przez modlitwę).

Kończąc, pragnę zauważyć, iż mam świadomość, że przedstawione tu fragmenty opowieści Zygmunta nie wyczerpują całości doświadczania przez niego jakości życia, jednakże ramy artykułu nie pozwalają na szerszą oraz głębszą analizę

${ }^{22}$ Uwidacznia się tu postawa homo transgressivus oraz homo esperanos, o których pisałam w zaproponowanych przeze mnie koncepcjach humanizmu transgresyjnego oraz humanizmu nadziei (Cymerman, 2007). W przytaczanej niejednokrotnie już książce starałam się nakreślić ramy konstruktu Szczegółowo o wdzięczności. 
narracji mojego rozmówcy. Podobnie rzecz się ma, jeśli chodzi o wszelkie aspekty wyznaczające obszary zainteresowań badawczych i działań pedagogów są jedynie zarysowane.

\section{Literatura}

Bardadin K. (1998). Transplantacje wątroby. [W:] Choroby wątroby i dróg żółciowych. Red. R. Brzozowski. Warszawa

Chańska W. (2009). Nieszczęsny dar życia. Filozofia i etyka jakości życia w medycynie współczesnej. Wrocław

Charakterystyka produktu leczniczego. Advagraf. http://www.ema.europa.eu/docs/pl_PL/document_library/EPAR_-_Product_Information/human/000712/WC500022234.pdf [dostęp: 10.07.2011]

Cinqualbre J., Wolf P., Ellero B., Boudjema K. (1993). Transplantacja narządów. Kompendium. Tłum. S. Michowicz, J. Michowicz, D. Patrzałek. Wrocław

Cymerman I. (2002a). Doświadczanie jakości życia przed przeszczepem organu. [W:] Człowiek i Człowieczeństwo - strategie bycia i stawania się człowiekiem. Fenomenologia Człowieczeństwa. T. 1. Red. H. Romanowska-Łakomy, H. Kędzierska. Olsztyn

Cymerman I. (2002b). Doświadczanie jakości życia po przeszczepie organu, [W:] Pedagogika wobec zagrożeń, kryzysów i nadziei. Red. T. Borowska. Kraków

Cymerman I. (2002c). Transplantacja organów jako problem społeczny oraz wyzwanie edukacyjne. [W:] Obszary zainteresowań pedagogów społecznych. Księga pamiątkowa poświęcona profesorowi Wiesławowi Wiczkowskiemu. Red. D. Zaworska-Nikoniuk. Olsztyn.

Cymerman I. (2003a). Doświadczanie jakości życia. Dylematy rodzin osób oczekujących na przeszczep lub będących po transplantacji organu. [W:] Psychologia w stużbie rodziny, s. 256-268. Red. T. Rostowska, I. Janicka. Łódź

Cymerman I. (2003b). Podarowane życie. Perspektywa życia i śmierci osób po przeszczepie narząu. [W:] Śmierć $i$ wiara w życie pośmiertne w świetle nauk przyrodniczych i humanistycznych. Red. M. Machinek. Olsztyn

Cymerman I. (2006). Przetrwanie - rozwój - transgresja w świetle badań jakościowych na temat doświadczania jakości życia po przeszczepie organu. [W:] Sapientia et adiumentum. W trosce o rozwój innych. Studia dedykowane profesorowi Zbigniewowi Kwiecińskiemu. Red. J. Michalski. Olsztyn

Cymerman I. (2007). Doświadczanie jakości życia po przeszczepie. Perspektywa fenomenologiczno-hermeneutyczna. Olsztyn

Drabarek A. (2004). Etyka umiaru. Ideał człowieka i jego szczęście w poglądach filozofów ze szkoły lwowsko-warszawskiej. Toruń

Knapik Z. (1998). Źółtaczka. [W:] Choroby wątroby i dróg żółciowych. Red. R. Brzozowski. Warszawa

Kokot F. (1998). Encefalopatia wątrobowa. [W:] Choroby wątroby i dróg żótciowych. Red. R. Brzozowski. Warszawa

Kowala-Piaskowska A., Figlerowicz M., Mozer-Lisewska I., Służewski W. (2005). Wyniki leczenia dzieci z przewlekłym zapaleniem watroby typu C pelygowanym interferonem i rybawiryna, „Przegląd Epidemiologiczny” t. 59, nr 2 
Morciniec P. (2007). Przeszczepy narządów. [W:] Encyklopedia bioetyki. Personalizm chrześcijański. Red. A. Muszla. Radom

Norkowski J.M. (2011). Medycyna na krawędzi. Ewolucja definicji śmierci człowieka w kontekście transplantacji narząów. Radom

Ostrowska U. (1998). Doświadczanie wartości edukacyjnych w szkole wyższej. Bydgoszcz

Rowiński W. (2003). Pozyskiwanie narządów do przeszczepiania - wkładem społeczeństwa w system opieki zdrowotnej, 05.04.2003 Częstochowa, „I Ogólnopolski Zjazd Organizacji Pozarządowych Działających na Rzecz Osób z Chorobami Wątroby" (materiały w posiadaniu autorki)

Sokolnicka H. (2003). Jakość życia pacjentów ze złamaniem w obrębie bliższej nasady kości udowej leczonych operacyjnie w Oddziale Urazowo-Ortopedycznym, http://borgis.pl/czytelnia/ nm_ortopedia/13.html [dostęp: 12.12.2003]

Szczerbań J. (1998). Przeszczepianie wątroby. [W:] Choroby wątroby i dróg żółciowych, Red. R. Brzozowski. Warszawa

Szymczyk J. (2004). Odkrywanie wartości. Wokół problematyki socjologiczno-aksjologicznej. Lublin

Thorwald J. (2010). Pacjenci. Kraków

Ustawa $z$ dnia 26 października 1995 r. o pobieraniu i przeszczepianiu komórek, tkanek i narzadów. Dz U. nr 138, poz. 622

Ustawa $z$ dnia 1 lipca 2005 r. o pobieraniu, przechowywaniu i przeszczepianiu komórek, tkanek i narządów, Dz.U. nr 169, poz. 1411

Ustawa $z$ dnia 17 lipca 2009 r. o zmianie ustawy o pobieraniu, przechowywaniu i przeszczepianiu komórek, tkanek i narząów oraz o zmianie ustawy - Przepisy wprowadzające Kodeks kar$n y$, Dz.U. nr 141, poz.1149.

Wielki słownik medyczny. (1996). Warszawa

\section{Individual After Transplantation Experiencing Quality of Live - Subject of Pedagogues Interest}

\section{Summary}

Pedagogy has been recently becoming more and more interdisciplinary, deriving from achievements of others humanities. In modern, complicated world it could be rather impossible not to benefit from such advantage, as it would push aside pedagogy and others fields of knowledge to margin, falling it back rather than giving them prospect of growth. That is why issue of organ transplantation, for instance, although it seems stricte medical problem, now expands area of pedagogy interests. It concerns all the situations having significance in experiencing quality of life by the pedagogical entities, so pupils in each age.

This text is based on description of experiencing life's quality of one person, living thanks to liver transplantation. It had been 10 years after surgery when Zygmunt was giving me interview. I hold a second conversation with him, as earlier he had been exchanging with me his experiencing quality of life. For the first time I met my interlocutor in September 2001, at that moment, he had been only three months after transplantation. Experiencing day-to day-reality of family, work, seeing with medical personnel during necessary consultation, this time were important for me. As a scientist I was interested also in changes that had been 
emerging and still appears in the context of quality life experiencing, from that moment when we had a first conversation. Feeling of life sense, recognized values were significant for me. Quality analysis, having attributes of phenomenological description of experiencing Zygmunt's quality life is often supplementing by medical, legal, ethical and religious data. I have done this, so that to in abbreviated way expose issues, shaping new research fields and new areas of educators' activities in the context of transplantation. Zygmunt's narrative is individual and for that reason it is not justified to make generalized conclusions. In the last part of text I am taking up efforts to justify significance of discussed issue (experiencing quality of life after transplantation).

Generally each oneself defines his life quality and in accordance with his glance subjectively evaluate personal life situation. As a rule man observes life in the prism of his personal experiences, in accordance with own system of values and life aspirations. Apart from that, values evolve just like history life's experiences, they are increasing. I have chosen three levels of life quality experiencing: low, ambivalent, and high/optimal. First level - low indicate serious dissonance between perfect state, that have been set by oneself, and experiencing reality. Ambivalent level concerns particularly such moments of life, when the situation of man "uncertain fortune" emerges, when it evolves rapidly, for instance: when the seriously ill state of health is changing. High/optimal level experiencing of life quality is typical for persons who are satisfied with their life, have the sense of it, they are fulfilling themselves by striving to personal aims. It is worth noted that, in the levels of experiencing one's life quality I do not locate extreme levels, that is lack of or level degenerated over the measurement. Since, it seems that it is possible to experience even very low quality of one's existence but not complete lack of it. Human being always feels „some” quality. In the second case, it is difficult to imagine someone who will recognize that he experiences life too high quality. Whereas the term of experience I comprehend as an immanent and permanent relation with oneself and people in life event. This relation characterize, constantly taking place transformation of experiencing also in the sphere of perception and internal world judgement or like in organ transplantation - partial rebuilding/regeneration body degraded by illness.

\section{New areas of pedagogy interest}

Consideration on possible interests for pedagogues in the context of organ transplantation I placed in Diagram 1. Areas of pedagogical interests connected with organ transplantation.

Diagram description: Draft represents fields of possible researches and pedagogical activities in relation of persons involved in organ transplantation. There are six type of entity: Donor/his Family/Nearest and Dearest, Person awaiting transplant/living with transplanted organ, Family/Relatives of patient, Doctors, Hospital personnel/Staff of post-transplantation clinic and Pedagogue. Educational interaction of Pedagogue would extended in 3 areas of anthroposphere. Each of this sphere has it own, separate part, designated only for specified group of people.

Specificity of pedagogical work in the area including donor and his relations (right part of diagram) concerns first and foremost transplantation education. It includes knowledge of legal aspects, ethics, religious and present accomplishments of medicine in that case. The heart of the matter is above all teaching, notification, but without propaganda. It is important that each individual autonomously, on the basis of reliable data, could make decision in the matter of giving consent or objection to explantation of his organs after his death or in the particular 
situation - as a living donor. Pedagogical activities addressed to Family and Donor's Relatives are generally the same, since nobody knows in which role will be one day: donor, recipient or someone relatives of the persons.

Second area of exploration and pedagogical activities (left part of diagram) relates to patient also before transplantation and after this surgery together with his relatives. Therefore there are also educational activities towards Donor (just before his falling ill), so that potential patient could be acquainted with subject matter, and not to consider transplantation as a death sentence. It seems also important that Pedagogue would accompany patient and his relatives. Then being together in values evolution could be a help. Changes degrading suffering body, because of it insufficiency cause increasing dependency from others. It is undoubtedly not simple, especially for adult, so far being responsible not for himself but for whole family. The most important turned out to be the fact, that in such illness necessary is organ received from other individual. Therefore it is essential to rely only on kindness of other person.

Third area ellipse outlined, placed on centre of diagram - here is essential relation of patient with doctor or other person employed at health care establishments. The most important aspect seems to be high quality meeting with patient. However attainment such level depends on do employee of health care establishment perceive in patient and in meeting with him value as it is. The idea is a respect of other person, „leaning” forward suffering through expressing common, human kindness. Accurate education is necessary so that to look like this at other human being.

Ellipses determining fields of researches and pedagogical activities are broken line outlined. It illustrates mutual permeating, coming over of each fields content. However every individual keeps many roles in his life, and it could happen for instance, that someone from medical personnel, is becoming organ recipient or donor's family. There are two-sided arrows among all entities. They symbolize mutual interactions and relations. There are non-accidental, curved lines, joining Donor with his family. Curve symbolizes relation, that occurred by the reason of transplantation which had been done, however the persons do not know each other personally (here it is mentioned transplantation ex mortuo). The Recipients are grateful to Donors for a new portion of life. Donor's family and recipient himself with the nearest and dearest are conscious of their existence and in their own way are trying to remember each other (for example by prayer) 